\title{
BRILLIANT DISGUISES: PERSONA, AUTOBIOGRAPHY AND THE MAGIC OF RETROSPECTION IN BRUCE SPRINGSTEEN'S LATE CAREER
}

\author{
RICHARD ELLIOTT
}

\begin{abstract}
Popular musicians with long careers provide rich source material for the study of persona, authenticity, endurance and the maintenance (and reinvention) of significant bodies of work. The songs of successful artists create a soundtrack not only to their own lives, but also to those of their audiences, and to the times in which they were created and to which they bore witness. The work of singers who continue to perform after several decades can be heard in terms of their 'late voice' (Elliott 2015a), a concept that has potentially useful insights for the study of musical persona. This article exploits this potential by considering how musical persona is de-and re-constructed in performance. I base my articulation of the relationship between persona, life-writing and retrospective narrativity on a close reading of two late texts by Bruce Springsteen: Born to Run, the autobiography he published in 2016, and Springsteen on Broadway, the audiovisual record of a show that ran from October 2017 to December 2018. In these texts, Springsteen uses the metaphor of the 'magic trick' as a framing device to shuttle between the roles of autobiographical myth-breaker and lyrical protagonist. He repeatedly highlights his songs as fictions that bear little relation to his actual life, while also showing awareness that, as often happens with popular song, he has been mapped onto his characters in ways that prove vital for their sense of authenticity. Yet Springsteen appears to be aiming for a different kind of authenticity with these late texts, by supplementing the persona developed in his earlier career with an older, wiser, more playful narrator. I appropriate Springsteen's 'magic trick' metaphor to highlight the magic of retrospection and the magical formation of the life narrative as an end-driven process.
\end{abstract}

\section{KEY WORDS}

Musical Persona; Autobiography; Narrative; Authenticity; Late Voice

\section{INTRODUCTION}

At the start of the two-minute spoken introduction to his Broadway show, as streamed on Netflix from 16 December 2018, Bruce Springsteen provides a litany of "elements that will come in handy" for anyone who finds themselves "face-to-face with eighty thousand screaming rock 'n' roll fans ... waiting for you to pull something out of your hat ... something that, before the faithful were gathered here today, was just a song-fuelled rumour" (Springsteen on Broadway 2018 , henceforth $S O B$ ). It is a routine that enables the veteran musician-who was 68 at the 
time the show was filmed-to do at least two things straightaway. Firstly, he breaks the ice by commenting on what is happening at that moment: an individual introducing himself to two expectant audiences, one in the theatre and the other on the other side of a screen. Secondly, he marks this event as different to those arena shows for which he has long been famous. The theatre audience is removed from the arena concert by the intimacy of the event, which is taking place-as it would for its 236-show run-at Manhattan's Walter Kerr Theatre, a venue with a capacity of less than 1000. The Netflix audience, meanwhile, is removed from the live experience altogether, experiencing the show as captured by director Thom Zimny and mediated through film production and the streaming platform. This difference between Springsteen as stadium rock star and theatre monologist finds a parallel in a series of mythbusting anecdotes that make up $S O B$ and which previously found voice in Springsteen's (2016a) autobiography Born to Run (henceforth BTR). ${ }^{\mathrm{i}}$ The introduction to the Broadway show is based on the two pages that make up the foreword to the autobiography, albeit re-ordered and rephrased to work more directly as speech.ii

As any orator knows, what works as written prose needs adapting for direct speech if it is to be affective and memorable for speaker and audience. However, the changes Springsteen makes to his $B T R$ script for $S O B$ are less surprising than the continuities from one medium to the other. Common to both is the framing mechanism of the magic trick, alluded to in $S O B$ by the line about pulling "something out of your hat" and more explicitly in what follows: "I'm here tonight to provide proof of life to that ever elusive, never completely believable ... 'us'. That's my magic trick. And like all good magic tricks, it begins with a setup" (SOB 2018). The book's narrator is inaudible and invisible (though some home-sourced photographs are included at the end of the book); the audiobook adds the author's speaking voice; the Netflix special adds the visual presence of the body; the Broadway show provides the aura of physical presence: all do their magic tricks in ways particular to their medium but all are involved in the work of dismantling, maintaining or rebuilding the "song-filled rumour". This raises questions as to whether Springsteen is creating a new persona or adding layers to existing personas, an ambiguity that gives these late narratives a considerable part of their appeal and which will be at the heart of this article.

Vital to the narrative of $S O B$ is the inclusion of sixteen songs drawn from across Springsteen's performing career, each interspersed with or interrupted by a series of monologues drawn from BTR. Springsteen uses the "magic trick" at the start and close of both the book and the Broadway show. In the former, it appears in the foreword and again at the end of the final chapter (Springsteen 2016a, p. 505), ahead of one final anecdote; in SOB, it is mentioned at the outset and again in the monologue that precedes Dancing in the Dark, not quite the last song of the show but close to the end. This device allows Springsteen to shuttle between the roles of life-writer, myth-buster and lyrical protagonist, repeatedly highlighting his songs as fictions that bear little relation to his actual life, while also acknowledging how he has been mapped onto the characters of his songs in ways that prove vital for their sense of authenticity. At the beginning of BTR and $S O B$ he offers the first of many confessions: "I come from a boardwalk town where almost everything is tinged with a bit of fraud. So am I. By twenty, no race-car-driving rebel, I was a guitar player on the streets of Asbury Park and already a member in good standing amongst those who 'lie' in service of the truth ... artists with a small 'a'" (Springsteen 2016a, p. xi). Yet, as we soon learn from these late projects, Springsteen is far from giving up on authenticity, supplementing the persona developed in his recorded work with an older, wiser narrator focussed on the late depiction of life, love and loss. He repeatedly presents his life as the thing he set out to achieve, able to do so with the useful and secure knowledge that he has achieved it and that he and everyone experiencing his narrative knows it; this is all part of the facade, part of the "magic trick". 
The retrospection allowed by lateness and successful ageing is key here. Popular musicians with long careers provide rich source material for the study of persona, authenticity, endurance and the maintenance (and reinvention) of significant bodies of work. Successful artists' songs create a soundtrack not only to their own lives, but also to those of their audiences, and to the times in which they were created and to which they bore witness. The work of singers who continue to perform after several decades can be heard in terms of their "late voice" (Elliott 2013, 2015a, 2015b), a concept that refers to chronology, vocal conviction, afterlife, retrospection, and the writing of age, experience, lateness and loss into song texts. In this article, I explore those aspects of lateness most pertinent to considering the musical persona, especially as it is de- and re-constructed in retrospective, autobiographical performance. In doing so, I present the multiplicity identified above as crucial to Springsteen's persona. The process whereby he simultaneously deconstructs and maintains his various personas provides a vital component to what I will call the 'affective pact' that he shares with his audience. My main primary sources here are Springsteen's autobiography and his Broadway show, though I also make use of interviews the artist has given to journalists and to some of the now voluminous critical writing devoted to him. In selecting from this body of work, I emphasise a set of recent texts that cover Springsteen's later career. iii

I proceed from two assumptions that are worth stating now. The first is general: that audiences are aware of and invested in musicians' personas. Indeed, they are more than invested, in that they play a vital part in maintaining these personas (Auslander 2004, 2006) and in using them to authenticate their (the audiences') own personas. My second assumption is particular to this case study: that Springsteen's audience is knowledgeable about his history. It could be argued that an audience with a less developed understanding might still wish to engage with these works and there is evidence from online commentators on review sites that people who profess not to like Springsteen's music find his autobiography interesting precisely because of its attempt at deconstructing his persona. However, the inclusion of so many mythbusting comments by Springsteen in these texts, the repeated quotation of these by reviewers, and the reactions by his Broadway audience to these comments, make a strong case for an artist and an audience who share a body of knowledge and/or assumptions that are based on the successful development of a set of musical personas over a sustained period of time. Combined, the two assumptions shared above mean that, even when I am presenting Springsteen as a "text" to be read, I see such reading as a productive act, recognising that Springsteen is producing his persona(s) in collaboration with the reader-producers who are his audience. The persona is both the thing that Springsteen is performing and an object of exchange and coconstitution circulated among a network of actors (Latour 2005). If "personas are the material forms of public selfhood" (Marshall, Moore \& Barbour 2015, p. 290), then the circulation of persona-objects is how these forms get materialised.

It is worth underlining that I am writing about a musician who has successfully maintained a career over decades, which may challenge some existing accounts of fame and celebrity applied to musicians' careers. Pop music careers have, for example, been presented in terms of "dissipation" (Marshall 2006, p. 217) or as a process in which an artist moves into fame as "a career in itself" (Turner 2014, p. 8). As a challenge to this, it is useful to consider the growing interest in long careers in which stars are seen as moving impressively into late style (Gardner 2012; Jennings 2012; Elliott 2015a, 2015b, 2015c). Dissipation may still be a key aspect of popular musicians' careers but it is far from being the final word in the story as we become more aware of the waxing, waning and second comings of pop careers across the life courses of artists and their audiences. Similarly, while some musicians who perform into later life may "freeze a popular persona" to re-present it on the "oldies concert circuits" (Auslander 2004 , p. 9), others are notable for reinventing and reframing their careers. In BTR, Springsteen 
narrates the concern he felt over his "midnineties drift" (2016a, p. 398), but this is only one episode of many more and he can look back from the retrospective space of autobiography to see this as a precursor to "the second half of my work life", which he dates to the composition of 1995's The Ghost of Tom Joad (Springsteen 2016a, p. 389).

\section{Persona}

Discussions about popular musicians' personas, especially for musicians considered over extended periods, are often guided by two dominant categories: the artist as shape-shifter and/or the artist as consistent, layered self. The former category tends to focus on the radical reconfigurations or "refractions" (Banauch 2015) evident in artists who have adopted several distinct personas; typical candidates include Bob Dylan, David Bowie and Madonna (Scobie 1991; Banauch 2015; Fouz-Hernández \& Jarman-Ivens 2004). The latter category tends to focus on the gradual enriching of the persona over time, via layers of experience that build on a solid core (Simmons 2013; Jennings 2012; Gardner 2012; Elliott 2013, 2015a, 2015c) and several recent accounts of Springsteen follow this model (Carlin 2012, Colombati 2017, Hiatt 2019). It would be a mistake, however, to think of these categories as exclusive binaries; the shapeshifting aspect of a star might be the most consistent thing about them, while the seeming consistency of the gradually layered self relies on the accumulation of multiple selves, some of which might be as varied as the shifting light across a landscape. We should instead consider a dynamic or dialectic tension between shape-shifting and layering, and indeed some of the above-cited studies have done this for Dylan, Bowie and Madonna, along with other studies that highlight consistency across the life course of these artists (Marshall 2007; Elliott 2015a; McMullan 2019; Watson \& Railton 2012). Joanna Demers (2017, p. 27) has even suggested that "the defining trait of [Bowie's] career was less his rapid and frequent stylistic metamorphoses than the consistency of his underlying persona" (see also Auslander 2004, p. 7).

This dialectical tension between shape-shifting and layering can be found in the personas associated with Bruce Springsteen. While it is often noted that he has maintained a consistent, if increasingly layered, self that dispenses with the aliases and pseudonyms of nearcontemporaries such as Dylan (see, Gross 2016, for example), Springsteen has also been presented as an artist with "multiple selves" (Cologne-Brookes 2018, pp. 140-54). There have even been comparisons with Bowie, such as when a Guardian review of $S O B$ reports that "Bruce Springsteen is as much a contrived character as Ziggy Stardust - a stadium-filling exaggeration of Springsteen's troubled factory-worker father - and that we should be wary of treating what he says as gospel" (Petridis 2018). Writing about Bowie's 1973 cover of Springsteen's Growin' Up, Chris O'Leary (2015, p. 310) suggests a recognition by Bowie of "a kindred spirit, a fellow self-mythologist whose instincts were theatrical ... Both were labelled magpies and imitators by critics, both would age into curators and revivalists". Springsteen himself has noted the multiplicity of personas he inhabits, sharing this self-objectification with audiences at concerts and in interviews. It is a quality he alludes to frequently in BTR and in interviews following the publication of the book. Discussing the creation of his onstage persona with Terry Gross in 2016, he recognised it as a site of desire and identification:

People see you on stage and, yeah, I'd want to be that guy. I want to be that guy myself very often, you know? I had plenty of days where I'd go, "Man, I wish I could be that guy." And there's a big difference between what you see on stage and then my general daily, my daily existence. (Gross 2016)

As Marshall and Barbour (2015, p. 2) note in the inaugural issue of Persona Studies, the notion of the persona can be traced back to the Greek use of wooden masks on stage that allowed "actors to play more than one role" while also creating the possibility for "a univocal identity" when 
different actors wore identical masks (for example, in the chorus). If we relate this dual possibility to the dialectic of shape-shifting and layering, we may understand how an artist such as Springsteen (or Bowie, Dylan or Madonna) could seem to be many different personas (by changing the masks) or the same persona (by maintaining the same mask while the person behind it changed). This accords with the idea of persona as "the relative and strategic posture of different versions of the self" (Marshall \& Barbour 2015, p. 4). In Springsteen's case, these have taken the form of nicknames and honorifics bestowed upon the artist over his career: the Boss, the Bard of Asbury Park, the New Dylan (see Streight \& Harde 2010 for these last two) and the seeming non-persona of the name chanted by audiences in stadia across the world: Bruce. Peter Ames Carlin provides a prologue to his 2012 biography, Bruce, in which he justifies his use of the simple first name term as the one that audiences use to build rapport with the artist. At the same time, he notes that "the Boss" started as an insider nickname and still holds that status for those in Springsteen's inner circle: "one of the privileges of being a Boss is controlling who can and can't call you that" (Carlin 2012, p. x). Carlin also notes the "Bruce-bestowed nicknames" given to Springsteen's bandmates and associates: "Southside [Johnny], Miami [Steve Van Zandt], Albany Al, and so on" (Carlin 2012, p. x ).

Then there are the different roles that Springsteen has played in his fans' lives. Reflecting on the evidence amassed in studies of Springsteen fans, such as Daniel Cavicchi's Tramps Like Us (1998) and in online resources such as backstreets.com, Irwin Streight and Roxanne Harde (2010, p. 7) write that the artist "is adored and venerated beyond rock star status, as would be a spiritual master, a pop philosopher, a revolutionary, a head of state, or a saint". Gavin Cologne-Brookes (2018, p. 141) notes the effect of the success of Born in the U.S.A. on the maintenance of Springsteen's personas:

By 1984 Bruce Springsteen had become 'Bruce Springsteen.' In the public eye, he was a postmodernist rock star with no actual heartbeat or voiding of the bowels: a cartoonish figure, epitomized by the lip-synced 'Dancing in the Dark' video, the Action Man pose on the album's inside cover, and-for an example of mass-media by-products-the sepiatinted, garish cover of the bio-catalogue Bruce Springsteen: Blinded by the Light (1985), where our hero, in superimposed, photo-brushed Technicolor, gazes askance a tequila sunglow and resembles a 1950s B-movie pirate matinee idol.

Cologne-Brookes' study recognises the changes that are wrought upon artists' personas as they encounter shifts in fame and fortune, as they continue to try and produce art in the face of this and-as Springsteen told a reporter in 1998-to not let celebrity "blur and obscure the story that [they're] interested in telling" (cited in Cologne-Brookes 2018, p. 143). Two decades later, Springsteen evidently felt the need to engage with this in new ways by making that blurring the very story he was interested in telling. $B T R$ and $S O B$ attest to this need or desire and also help us to consider the ongoing unfolding of Springsteen's persona over time and how this relates to authenticity. As Richard Peterson (1997) demonstrates regarding genre, the extent to which authenticity can be thought of as a "renewable resource" is intimately connected to what is considered credible at different historical moments. So too with individual careers and authenticity across the life course: the authentic Springsteen of 2018 needs to be different to the authentic Springsteen of the 1990s, which in turn was different to that of the 1970s and 1980s. This is equally the case with representations. The sepia tinted photograph that Cologne-Brookes highlights tells us as much about graphic design choices of the 1980s as it does about fame and persona. In another vein, the emphasis on celebratory life-writing found in the canonical literature on Springsteen (Marsh 1979 and 1987 being the most cited examples) seems to require a critical counterpoint that provides a more nuanced account of the life course and which considers the cultural milieu in which Springsteen's late career unfolds. It is important 
that contemporary biographical narratives (such as those cited in this article) feel right for right now. This notion of changing authenticity may not always be in line with the expectations of fans, some of whom might prefer to live with the myths that the older Springsteen seems so keen to dampen and who might prefer the Boss to get out on the road with the band for some "proper" concerts. However, it seems as likely that a large proportion of Springsteen's long-term fan base will recognise the need for him to articulate his inhabitation of the personas of son, parent, husband, friend, bandleader, and so on, not least if they are looking for him to reflect some of their own experiences. What BTR and $S O B$ provide, then, is not just the narration of these aspects of Springsteen's persona(s), but the addition of a new (or newly foregrounded) persona, the wise, "late" storyteller operating retrospectively. What we also witness in Springsteen's presentation of wisdom-as-lateness and lateness-as-wisdom is the "heroic" taking on of the role of self-narrator rather than the one who is narrated by others. iv This can be seen as an appropriation of one's "narratability", a term that Adriana Cavarero (2000) uses to recognise the latent layers of narrative in all of us, from the unconscious workings of our memory to the conscious acts of remembering and self-narration. At the same time, in Springsteen's case, we should remember that we are dealing with someone who has consistently taken on the role of hero-narrator. In addition, Springsteen has long acted as one whose story will have been told or one whose destiny was always to star in a particular kind of narrative, built on tropes of "pulling out of here to win", "no surrender", and a refusal to "give up living" (lyrics from, respectively, Thunder Road, No Surrender and Racing in the Street).

\section{(Auto)biography}

Perhaps one of the defining traits of the popular music persona, in contrast to the personas of other stars and celebrities, is the ingrained tendency in popular song to conflate the " $\mathrm{I}$ " of the singer with the "I" of the lyric. The processes whereby the opinions, desires and intentions of lyrical protagonists are confused with those of the composers and performers who bring them to life is part of the authenticating work done by popular musicians and their fans (Frith 1996; Auslander 2004). While it is certainly possible to speak of different voices at work in classical song (see Cone 1974), there is arguably a stronger sense of the mediations at work in that practice, just as there is with actors on stage or screen. The tendency to read lyrics as autobiography in popular song leads to a species of interpretative debate amongst its critics and fans that would seem out of place discussing other arts. It is a confusion that Springsteen relies upon in $B T R$, and, to an even greater extent (because it is delivered in a more concentrated form), in $S O B$. Among the most reported of the myths he sets out to bust in the book and the show, are the following (quoted from $S O B$ ):

- "I've never worked five days a week until right now. [Pause]. I don't like it!"

- "I've never seen the inside of a factory, and yet it's all I've ever written about."

- "Standing before you is a man who has become wildly and absurdly successful writing about something of which he has had [dramatic pause] absolutely no personal experience."

- "I made it all up! That's how good I am."

- $\quad$ [on revealing that he lives ten minutes from his hometown:] "Born to Come Back': who'd have bought that shit?" 
These revelations also act as moments of humour in Springsteen's narrative, something he had earlier brought out strongly in the audiobook of BTR (Springsteen 2016b) and builds on with dramatic pauses and shifts in vocal register in $S O B$. This is all part of the strengthening and foregrounding of his narrator persona.

As Springsteen repeatedly distances himself, in the autobiography and Broadway show, from the "I" of the songwriter and performer, a shift of authenticity occurs. We are now asked to believe that the "I" of the autobiography is the truth-teller, the one who tells it as it really is. At the same time, the references to the continuation of the magic trick and the occasional detours into poetic, biblical and literary narrative styles offer clues that we are still under the spell of some illusion. This illusion does not prevent Springsteen from making pronouncements that come across like profound experiential insights or lasting truths. In this way, he seems to exemplify an observation made by the pioneering theorist of autobiography, Philippe Lejeune: "Telling the truth about the self, constituting the self as complete subject-it is a fantasy. In spite of the fact that autobiography is impossible, this in no way prevents it from existing" (Lejeune 1989 , pp. 131-2). This continuous illusion is perhaps something we already know from pop artists, because the conflation of singer and lyrical protagonist is similarly an effective fantasy, part of a set of "thought-fictions" we like to tell ourselves about music (Demers 2017).

By Lejeune's early definition of autobiography-“Retrospective prose narrative written by a real person concerning his own existence, where the focus is his individual life, in particular the story of his personality" (Lejeune 1989, p. 4) — only BTR, of Springsteen's late memory projects, would count as true autobiography. Yet it is possible to recognise what Lejeune calls "the autobiographical pact" in all the texts being considered here, as well as in Springsteen's longstanding practice of storytelling at his concerts. Lejeune's initial description of the pact, as set out in an influential article in 1973, is based on the observation that "[i]n order for there to be autobiography (and personal literature in general), the author, the narrator, and the protagonist must be identical" (Lejeune 1989, p. 5).v We might wonder how the autobiographical pact might work for the self-confessed fraudster who narrates his story in $B T R$ and $S O B$. Is it worth, for example, making a distinction between a truth presented in the act of narrating the self and a veridical truth to which it must bear some correspondence but not always map onto directly? Lejeune does allow for some flexibility in autobiography that distinguishes the practice from the demands of factuality in third-person biography. As Paul John Eakin notes, the emphasis in the autobiographical pact given to enunciation (énonciation) over utterance (énoncé) marks it out from the more veridical demands of biography: "Unlike biography, where the resemblance of the protagonist to the verifiable facts of the life of the historical model constitutes the decisive criterion for authenticating its structure of reference, in autobiography such resemblance is of distinctly secondary importance" (in Lejeune 1989, p. $\mathrm{x}$ ). Furthermore, as noted already, popular song-the area in which Springsteen has plied his trade-has its own kind of autobiographical pact, one which would not necessarily be recognised by Lejeune (due to his insistence on prose as a condition for autobiography) but in which, nevertheless, the frequent conflation between the "I" of the songwriter, singer, and lyrical protagonist suggests its own promises, commitments and affective misreadings. Springsteen recognises this himself by explicitly comparing his song lyrics with his "real" life in $B T R$ and $S O B$ and by making explicit mentions of the pact he is making with his audience that are in keeping with the themes of many of his songs (The Promise, Promised Land, No Surrender). In BTR, he admits, “I haven't told you 'all' about myself ... But in a project like this, the writer has made one promise: to show the reader his mind. In these pages I've tried to do that" (Springsteen 2016a, p. 501). 
When Terry Gross interviewed Springsteen on the release of $B T R$, she asked him about the construction of his stage persona and whether he felt it "[drew] both from the angry and uninhibited side ... and the more inhibited, timid side" that he had shared in his autobiographical reflections. Springsteen responded by saying:

I think it's both there ... if you just looked at the outside, it's pretty alpha-male, which is a little ironic, because that was personally never exactly really me. I think I created my particular stage persona out of my dad's life and perhaps I even built it to suit him to some degree (Gross 2016).

He then alluded to a passage in the book in which he talks about taking on his father's voice:

Those whose love we wanted but could not get, we emulate. It is dangerous but it makes us feel closer, gives us an illusion of the intimacy we never had. It stakes our claim upon that which was rightfully ours but denied. In my twenties, as my song and my story began to take shape, I searched for the voice I would blend with mine to do the telling. It is a moment when through creativity and will you can rework, repossess and rebirth the conflicting voices of your childhood, to turn them into something alive, powerful and seeking light. I'm a repairman. That's part of my job. So I, who'd never done a week's worth of manual labor in my life (hail, hail rock 'n' roll!), put on a factory worker's clothes, my father's clothes, and went to work (Springsteen 2016a, p. 414).

This passage, which Springsteen presents in slightly modified form before his $S O B$ performance of My Father's House, does a lot of work itself. Not only does it provide a more nuanced version of the myth-busting that permeates BTR and SOB (I sing about things I have no experience of), it also provides insights into the construction of persona through intimate connections and disconnections. Returning to the notion of persona as the wooden mask through which the actor speaks, is it too fanciful to think of Doug Springsteen as the blank and inert facade brought to life by his son's performance and, simultaneously, of the singer-actor's need of the mask that was his father's indifference to make the transformation from introvert to extrovert? Given that these are the kinds of connections the post-therapy Springsteen himself makes at various points in the book, in his show and in a number of late interviews, it seems not. As he told Terry Gross, "most people's stage personas are created out of the flotsam and jetsam of their internal geography and they're trying to create something that solves a series of very complex problems inside of them or in their history" (Gross 2016).

Another aspect to note here is Springsteen's reference to Chuck Berry's song School Days and its iconic lyric "Hail, hail rock ' $n$ ' roll"; it is a typical recognition by Springsteen of the workings of identification in popular music. Elsewhere (Elliott 2008) I have discussed the identification processes in Berry's song in connection to Louis Althusser's (1971) account of ideology and interpellation and Alain Badiou's (2005) theory of event. Rock 'n' roll, I have argued, creates subjects who are faithful to its event and who recognise themselves as addressees of its hail. Springsteen's narratives-from his early concert monologues to his recent autobiographical projects-have long been dedicated to asserting (even preaching) this recognition. Having recognised himself as a subject and glimpsed his possible destiny in the event of rock 'n' roll (Springsteen 2016a, pp. 38-53), he is aware of the ways in which his audience witness something in the persona he presents to the world. There is much labour involved in the taking on of this power but, when the transformation is successful, a career is possible. Berry's School Days recognises this in its promotion of rock 'n' roll as an alternative to school and "regular" work; Springsteen's disavowal of manual labour, meanwhile, is belied by his own reputation as a hardworking bandleader who "sweats it out" in ways unmatched by many of his fellow performers. 
Springsteen makes further use of the intimacy of autobiography by devoting much of $S O B$ to the accounts provided in $B T R$ of family and friends; we are treated to monologues about his childhood, his parents, his pre-fame friends, his bandmates, and his wife and children. In the shows recorded for the Netflix special, Springsteen's wife Patti Scialfa joined him for two duets, allowing for a more intimate display of their domestic situation than would be typical at a Springsteen show. As Marshall and Barbour (2015, p. 6) observe, "the contemporary moment produces new pushes towards both forms of revelation and forms of performativity that allow the social to move into the territories of the previously private and intimate". They are thinking here of the use of social media, and it is certainly the case that for many musicians-especially those of a younger generation than Springsteen - the blending of personal and public has become ever more noticeable, with Twitter-using musicians writing what often amount to continuous autobiographies. Even aside from social media, however, there is a sense of a new kind of intimacy being deployed by Springsteen as he reflects on love and relationships with Scialfa standing beside him. Following their rendition of Tougher than the Rest, Springsteen speaks about relationships in terms of letting people see our real selves, "allowing others to see behind our many masks". This opening of the self to others through love and trust is put into question again when the couple perform Brilliant Disguise, a song about the uncertainty of getting behind the mask. vi We are also alerted here to the co-constitution of personas between actors in a network or other relationship and of brilliant disguises as objects emerging from the processes of identification when selves present themselves to each other.

\section{Narratives}

Towards the end of his autobiography, Springsteen observes, "Writing about yourself is a funny business. At the end of the day it's just another story, the story you've chosen from the events of your life" $(2016 a, 501)$. This is a reminder of a point made by many theorists of narrative with regard to the retrospective selection of significant and insignificant events. Hayden White (1980, p. 14), for example, writes that "every narrative, however seemingly 'full,' is constructed on the basis of a set of events which might have been included but were left out". What, then, are the elements chosen for inclusion in Springsteen's late memory projects? The answer will depend, of course, on which of the projects we wish to consider. For the purposes of this article, it is best to begin with the more compact project of $S O B$. That said, there are many narrative points that we can map from $S O B$ onto $B T R$, as well as a range of distinct narrative strategies that we can attach to both projects and to other works produced by and about Springsteen. With the mutual construction of persona in mind, we should also recognise the role of Springsteen's audience in this selection process. As Philip Auslander (2006, p. 115) observes,

Audiences try to make performers into who they need them to be, to fulfill a social function. A successful working consensus means that such a relationship has been achieved. If one thinks of audiences not just as consumers, but also as the co-creators of the musicians' personae, and as having a substantial investment in those personae and the functions they serve, it is easy to understand why audiences often respond very conservatively (in the literal sense) to musicians' desire to retool their personae.

As fans we have to be willing to reignite our belief in the artist at each new narrative event; in the case of $B T R$ and $S O B$, this means buying into a persona who is telling us things we probably already know (that Springsteen is not the central character of many of his songs) but in newly affective ways. By this I do not mean that the mode of delivery has to be new (although here it is), but rather that affect relies on newly (re)engaged emotional responses.

Firstly, we can observe that $S O B$ opens with a classic storytelling scene. A man walks onto a stage and attempts to spellbind his audience, to perform a magic trick, to pull something 
out of the hat. He needs to beguile, to win over, to tempt, but this is less a siren song and more a rime of an Ancient Mariner, an invitation to share the negotiation of stormy seas and occasionally traumatic events from the safe distance of the storyteller's circle. It is not the odyssey, but the telling of the odyssey. It begins, as Springsteen tells his audience, with a "setup" and within a second of him telling us this, we hear the opening chords to one of his most enduring songs: Growin' Up. It is an apt choice, allowing Springsteen to start with an early song that recounts an even earlier experience. Whether the experience related in the song is real, imagined, aesthetic or a combination of all of these and more seems unimportant; what matters is that the audience is on-board. Many will have heard this song used at previous concerts and will know it as a song frequently prefaced or interrupted by monologues. So it proves to be here as well: Springsteen stops singing after less than two minutes and, over the continued guitar figure from Growin' Up, starts his myth-busting routine. Having established "how good I am" (at creating art from experiences he has not had), he offers to tell his listeners how "this great miracle [came] to pass". Slipping briefly into a new voice for the first of many biblical allusions, he intones, "In the beginning, there was a great darkness upon the waters", which his audience might recognise not only from the Bible, but also from the opening to "The Big Bang", the seventh chapter of $B T R$, in which Springsteen relates the coming of Elvis as the major event of his childhood. His main narrative begins, then, with the emergence of rock ' $n$ ' roll, delivered with the fire and certainty of a testifying preacher. This is rock ' $n$ ' roll as personal and cultural event, with Elvis cast as a revolutionary force, along similar lines to John Trudell's poem Baby Boom Ché (Trudell 1992, Elliott 2008).

A narrative about a narrative is like a map about a terrain: what scale do we choose? To go through the odyssey of $S O B$ (let alone $B T R$ ) in a blow-by-blow fashion would be absurd and unnecessary. Let us instead note different ways in which we can draw the map. One way to present the narrative would be as a stripped-down list of the main topics Springsteen covers in SOB: self, Elvis, hometown, father, mother, the road, the land, lost friends, Clarence Clemons, Patti Scialfa, family, democracy, social justice. The narrative could also be listed as a set of the songs that these episodes introduce or interrupt: Growin' Up, My Hometown, My Father's House, The Wish, Thunder Road, The Promised Land, Born in the U.S.A., Tenth Avenue Freeze-Out, Tougher Than the Rest, Brilliant Disguise, Long Time Comin', The Ghost of Tom Joad, The Rising, Dancing In the Dark, Land of Hope and Dreams, Born to Run. vii This telescoping of the narrative allows us to parse quickly the flow of the Broadway show and to get a sense of its arc. It also mounts a certain kind of victory over time. As White puts it, "narrative strains to produce the effect of having filled in all the gaps, to put an image of continuity, coherency, and meaning in place of the fantasies of emptiness, need, and frustrated desire that inhabit our nightmares about the destructive power of time" (White 1980, p. 15).

In starting to square narrativity with persona, we might ask how the maintenance of persona serves a similar purpose and to what extent Springsteen's deconstruction of his persona can be seen as a revisionist history, a new way of telling a seemingly familiar story because there is a lot of familiarity in the narratives of BTR and SOB. While Springsteen may not have shared as much about himself in as sustained a fashion before, he has told some of these stories, and performed and recorded these songs before. The recurring stories that Springsteen has told at concerts throughout his career can themselves be concertinaed into micronarratives, as Daniel Cavicchi (1998, pp. 28-9) does by conflating several versions of Springsteen's early pre-Growin' Up monologues into one version. This monologue, which has long functioned for Springsteen as a retrospectively attributed sense of forward planning, fate and vision in his younger self, is variable but consistent enough in its main themes and details for Cavicchi to be able to caricature it effectively (see, also, Rauch 1988). 
From a more critical perspective, a 1985 review by Biba Kopf of Springsteen at the height of the fame that came with Born in the U.S.A., uses a similar micronarrative in its adoption of suspicion regarding the artist's myth-making. Accusing Springsteen and his audience of wallowing in nostalgia while offering only melancholy in response to the problems of the present, Kopf sees the purpose of the pre-song raps as ways of presenting the subsequent heroic performances as the solution to any problem or as the proof that the gamble of youth paid off:

The rage ... is shortlived. Here comes another "I remember..." to disperse it, more nostalgia for cars, gals, guitars, waterholes, rivers, endless rock 'n' roll summers. The further the Summer of Youth recedes into Springsteen's memory, the more warmly he reheats it, remoulding the component parts into the shape of rock'n' roll eternals, asserting through [the] sheer energy of his stagecraft and his undeniably likeable nature that there is only one way forward and it shimmies like this. That is, like it always has done (Kopf 1985).

Running alongside this nostalgia is a desire to be older, wiser and more experienced: "he wants to feel every wrinkle being etched into his forehead" (Kopf 1985). From the perspective of more than three decades later, it could be argued Springsteen's closing of his Broadway show with Born to Run is a continuation of this same old trick. Even with all the insight that comes with really being older, wiser and more experienced, is he still converting all the concerns he has raised into a problem for which the only solution is a classic rock song?

Perhaps. But then this is theatre and theatre serves many functions and uses many strategies. Kopf's analysis of the 1985-model Springsteen ultimately offers no other solutions itself, failing to explain what an alternative (but presumably still utopian?) act of "musicking" might entail (Small 1998). It also presents a simplistic notion of nostalgia, one that more nuanced accounts of the "condition" have sought to challenge (see Pickering \& Keightley 2006). My purpose in invoking Kopf, however, is not to argue with his analysis (which, after all, only partakes of a version of the same myth-busting that Springsteen himself would later adopt), but to use it as an example of how time, age, experience, memory and nostalgia work in autobiographical narratives to construct the multiple selves of those narrating and those witnessing the narration. Such witnesses bring their own narratives to the event and Kopf is therefore right to highlight the relationship between Springsteen and his audience and to note that it is built on the artist's likability. Indeed, I would argue that this likability is precisely the point, that it is key to the affective (and effective) work done by the Springsteen persona and that it is the tie that binds the layers that have rippled through that persona over the years. It is Springsteen's likability as much as the narratives of the everyday that he has told that has meant his fans have been able to identify with him and feel that, despite his incredible success, he is still speaking for, with and of us. As fans, our own personas are authorised and legitimised by the process of identification that takes place in the circulation of meanings between our representative artists and us. We might think of this as the affective pact between Springsteen and his audience.

This pact is attained and affirmed through differently mediated voices. In the book of $B T R$, Springsteen writes about wanting to find a voice with which to speak. The reader can savour the results and hear whichever voice they wish. In the audiobook version, listeners are given the author's spoken voice and a different kind of intimacy is created. It is a storytelling voice that can accompany us while doing other things; it can be taken in shorter bursts or longer bursts and replayed to allow favourite vocal moments to be enjoyed. There is a different intimacy to the Broadway show, which varies again, depending on whether one experienced it in the theatre or via audio-visual media. One of the notable aspects of Springsteen's delivery in 
$S O B$ is the way he uses the microphone, sometimes using it "naturally", sometimes using its amplification technology to make sound effects, sometimes moving away from it to speak to the audience "directly" and making use of the intimacy of the venue. For those in the theatre, this last technique could make it seem like they were closer to the "real Bruce"; for those experiencing it through the recording, there is an uncanny cutting-out of the voice that does its own kind of authenticity work, reminding us of our distance from events but simultaneously underlining the "realness" of the show. The different connections made through these different ways of accessing Springsteen's late autobiographical work underline the affective pact and provide a sense of getting to know the "real Bruce", even as he is telling us that he is performing a magic trick for us. This collaboration-his setting up of the artifice of the affective pact, our submitting to it-is one of the reasons that some critical voices accuse Springsteen of fakery; but it is also the very thing upon which his personas-shape-shifting and/or layered as they are-are built.

\section{Conclusion}

There are many ways to narrate a rock 'n' roll life and each holds the possibility of unveiling new personas (see Stein \& Butler 2015). There are the personas of the different selves that artists, like other humans, go through over the course of a life; then there are the personas adopted or applied by the creators of those different narratives. The author of a written memoir adopts a different persona to the writer of a song; the compiler of lyrics takes on a different role to the compiler of photographs. The interviewee, the photographic subject and the authoriser of sanctioned material take on different roles again. As Thomas Swiss (2005, p. 292) notes in his account of Marianne Faithfull's autobiography, "[b]eing 'imaginative' musically is what we often admire most about our favourite rock musicians, but of course being imaginative in [written] language requires different skills and experiences". By successfully adopting "literary" language and "poetic" techniques, Faithfull can present herself as narrator and subject "as a composite of 'personas' rather than as a single, unified, authentic self" (Swiss 2005, p. 292). So too with Springsteen, who presents various incarnations of himself as the subject of his story while also offering his audience the new personas of literary prose stylist, audiobook narrator and theatrical monologist. Sidonie Smith (1995, p. 18) writes that

Autobiographical narration begins with amnesia, and once begun, the fragmentary nature of subjectivity intrudes. After all, the narrator is both the same and not the same as the autobiographer, and the narrator is both the same and not the same as the subject of narration. Moreover, there are many stories to be told and many different and divergent storytelling occasions that call for and forth contextually-marked and sometimes radically divergent narratives of identity.

As autobiographer, Bruce Springsteen offers to take his readers and listeners closer to his real self than he ever has before and he offers to do so through the intimacies afforded by different platforms: book, audiobook, Broadway show, streaming video and audio, soundtrack albums on CD and vinyl. At the same time, he tells us that it is a new form of "setup" as he unveils his latest brilliant disguises: the prose stylist, the verbal storyteller, the theatrical dramatist, the stage actor (a different but related stage actor to the one he has been throughout his performing career). He offers a glimpse of his everyday self and removes himself from the scene, replacing the protagonist of the drama with the dramatist, or rather a newer kind of dramatist than we have known him as previously. He tells his audience that he is just a regular person like us (a tramp like us, perhaps), that he is a great deceiver and a master of transformation. Again, we might say that the clues were always there, that he has long been authenticated as a literary figure, a writer of the great American novel in the form of songs, albums and concerts (see 
Colombati 2017; Cologne-Brookes 2018; Hiatt 2019). If Springsteen's role as literary figure is made more explicit by his turn to prose in his memoir and the script for his Broadway show, it is nevertheless relatively easy, from a retrospective position, to trace the many precursors of such prose exercises in the stories Springsteen has practised and perfected over his performing career. Likewise, as $S O B$ and the audiobook of $B T R$ make evident (and what is already latent in the written text of $B T R$ ), musicians' autobiographies are further performances, to be read or heard as extra layers of the musical works with which they achieved fame (Stein \& Butler 2015).

But if it has become easy for others to retrospectively trace Springsteen's career as an autobiographer, the artist's own uses of hindsight are equally important to underline. In his late work, Springsteen seems to want to have things at least two ways: to have been the young man with the vision-as described in Growin' Up - and to be the older man who narrates the young man's vision. The autobiographical narrative, created in the present, attempts to re-present the thinking of the younger Springsteen at these various stages in his life. Narratives can be successful even through the flattening and distorting media in which they are presented (Cobley 2014); if the representation of the younger Springsteen is made credible by the operation of the signs exchanged between the older performer and his audience, credibility is assured.

Springsteen aims for this credibility with the sincere craft of his prose stylings and with his use of them to address his audiences directly, whether through the page, the stage or the recording. To take an example from the end of his Broadway performance:

I always thought I was a typical American... I studied and I played and I worked ... I wanted to know the whole American story. I wanted to know my story, your story; I felt that I needed to understand as much of it as I could in order to understand myself. Who was I? ... I wanted to be able to tell this story to you. That was my young promise to myself and this was my young promise to you ... This is what I pursued as my service. I still believe in it as such. This is what I've presented to you all these years as my long and noisy prayer, as my magic trick.

Springsteen follows this with more in a similar vein, making a case for his service to the audience ("you") and our importance to him, then shifting into one of his favourite registers, the testifying rock 'n' roll preacher. Then he performs Dancing in the Dark and we have a choice: take it as magical resolution, or dwell on the suggestion that what is first thought of as magic later comes to be explained as science, craft, labour and service. That process involves our labour too, the work we put into authenticating artists and authorising their personas.

\section{END NOTES}

' For an account that presents the earlier Springsteen as already a monologist (in his songs as much as in his concerts), see Rauch (1988). For another description of "magical myth-busting" in $S O B$, see Petridis (2018).

ii This process of turning the text of $B T R$ into the speech of $S O B$ was doubtless aided by Springsteen's experience of recording BTR as an eighteen-hour-plus audiobook (Springsteen 2016b).

iii Scholarly reflections on $B T R$ and $S O B$ were only starting to emerge at the time of writing this article; Edgerton (2019) provides an account that connects the late narratives and places them into the broader span of Springsteen's career.

iv On the narratability of the hero figure, see Cavarero (2000). For the role of the hero in Springsteen's work, see Gencarelli (1994). 
v For another, predominantly Anglophone, tradition that dealt with similar definitional and conditional aspects of autobiography in parallel with - but not always in dialogue withLejeune's work, see Olney (1980) and Gunn (1982). For a useful work that brings these traditions together, see Marcus (1994). For an account of the autobiographical pact in relation to popular music biography, see O'Dair (2019).

vi In his book, Springsteen writes, "My wife is a private person, not known through whatever her 'public persona' may be, and not nearly as fond of the limelight as I" (Springsteen 2016a, p. 373).

vii This is the list of songs included in the Netflix film and on the separately released soundtrack and, as such, represents a slightly exaggerated version of any one particular night of the show, in which most but not all of these tracks were included; details in the variations of the setlist can be found easily online.

\section{WORKS CITED}

Althusser, L 1971, Lenin and Philosophy and Other Essays, trans. Ben Brewster, NLB, London, pp. 123-73.

Auslander, P 2004, 'Performance analysis and popular music: A manifesto', Contemporary Theatre Review, vol. 14, no. 1, pp. 1-13, doi: 10.1080/1026716032000128674.

- 2006, 'Musical personae', The Drama Review, vol. 50, no. 1, pp. 100-119.

Badiou, A 2005, Being and event, trans. O Feltham, Continuum, London.

Banauch, E 2015 (ed.), Refractions of Bob Dylan: cultural appropriations of an American icon, Manchester University Press, Manchester.

Carlin, B 2012, Bruce, Touchstone, New York.

Cavarero, A 2000, Relating narratives: Storytelling and selfhood, trans. PA Kottman, Routledge, London.

Cavicchi, D 1998, Tramps like us: Music and meaning among Bruce Springsteen fans, Oxford University Press, New York.

Cobley, P 2014, Narrative, second edition, Routledge, London.

Cologne-Brookes, G 2018, American lonesome: The work of Bruce Springsteen, Louisiana State University Press, Baton Rouge.

Colombati, L 2017, Bruce Springsteen: Like a killer in the sun: Selected lyrics 1972-2017, trans. F Bolza, Backbeat, Milwaukee.

Cone, ET 1974, The composer's voice, University of California Press, Berkeley.

Demers, J 2017, Anatomy of thought-fiction: CHS report, April 2214, Zero, Winchester: Zero.

Edgerton, GR 2019, 'Repurposing Bruce Springsteen: A portrait of the artist as an old man', CST Online, 1 January, retrieved 6 February 2019, <https://cstonline.net/repurposingbruce-springsteen-a-portrait-of-the-artist-as-an-old-man-by-gary-r-edgerton/>

Elliott, R 2008, 'Popular music and/as event: Subjectivity, love and fidelity in the aftermath of rock 'n' roll', Radical Musicology, vol. 3, <http://www.radicalmusicology.org.uk/2008/Elliott.htm>.

- 2013, Nina Simone, Equinox, Sheffield.

- 2015a, The late voice: Time, age and experience in popular music, Bloomsbury Academic, New York.

-2015b, 'Across the evening sky: The late voices of Sandy Denny, Judy Collins and Nina Simone', in C Haworth \& L Colton (eds), Gender, Age and Musical Creativity, Ashgate, Farnham, pp. 141-53.

- 2015c, 'Words from the New World: Adventure and memory in Patti Smith's late voice', C Chastagner (ed.), Patti Smith: Outside, Presses Universitaires de la Méditerranée, Montpellier, pp. 113-35.

Fouz-Hernández, S \& Jarman-Ivens F 2004 (eds), Madonna's drowned worlds: New approaches to her cultural transformations, 1983-2003, Ashgate, Farnham. 
Frith, S 1996, Performing rites: On the value of popular music, Oxford University Press, Oxford. Gardner, A 2012, 'Framing Grace: Shock and awe at the ageless black body', in R Jennings \& A Gardner (eds), 'Rock On': Women, ageing and popular music, Ashgate, Farnham, pp. 6586.

Gencarelli, T 1994, “'Trying to learn how to walk like the heroes': Bruce Springsteen, popular music, and the hero/celebrity", in SJ Drucker \& RS Cathcart (eds), American heroes in a media age, Hampton Press, Cresskill, pp. 281-98.

Gross, T 2016, 'Bruce Springsteen: on Jersey, masculinity and wishing to be his stage persona', Fresh Air, NPR, 5 October, retrieved 2 April 2019, <https://www.npr.org/2016/10/05/496639696/bruce-springsteen-on-jerseymasculinity-and-wishing-to-be-his-stage-persona>.

Gunn, JV 1982, Autobiography: Toward a poetics of experience, University of Pennsylvania Press, Philadelphia.

Hiatt, B 2019, Bruce Springsteen: The stories behind the songs, Carlton, London.

Jennings, R 2012, 'It's all just a little bit of history repeating: Pop stars, audiences, performance and ageing', in R Jennings \& A Gardner (eds), 'Rock On': Women, ageing and popular music, Ashgate, Farnham, pp. 35-52.

Kopf, B 1985, 'Bruce Springsteen: At Wembley Stadium', New Musical Express, 13 July, retrieved 25 February 2019, Rock's Backpages <http://www.rocksbackpages.com/Library/Article/bruce-springsteen-at-wembleystadium>.

Latour, B 2005, Reassembling the social: An introduction to Actor-Network-Theory, Oxford University Press, Oxford.

Lejeune, P 1989, On autobiography, ed. P.J. Eakin, trans. K. Leary, University of Minnesota Press, Minneapolis.

Marcus, L 1994, Auto/biographical discourses: Theory, criticism, practice, Manchester University Press, Manchester.

Marsh, D 1979, Born to run: The Bruce Springsteen story, Dolphin, New York.

- 1987, Glory days: Bruce Springsteen in the 1980s, Pantheon, New York.

Marshall, L 2007, Bob Dylan: The never ending star, Polity, Cambridge.

Marshall, PD 2006, "The meanings of the popular music celebrity: The construction of distinctive authenticity', in PD Marshall (ed.), The celebrity culture reader, Routledge, New York, pp. 196-222.

Marshall, PD \& Barbour, K 2015, 'Making intellectual room for persona studies: A new consciousness and a shifted perspective', Persona Studies, vol. 1, no. 1, pp. 1-12.

Marshall, PD, Moore, C and Barbour, K 2015, 'Persona as method: exploring celebrity and the public self through persona studies', Celebrity Studies, vol. 6, no. 3, pp. 288-305, doi:10.1080/19392397.2015.1062649.

McMullan, G 2019, 'Constructing a late style for David Bowie: Old age, late-life creativity, popular culture', in D Amigoni and G McMullan (eds), Creativity in later life: Beyond late style, Routledge, London, pp. 61-76.

O'Dair, M 2019, 'Pacts, paratext, and polyphony: Writing the authorised biography of Robert Wyatt', Life Writing, vol. 16, no. 2, pp. 279-94, doi:10.1080/14484528.2019.1548265.

O'Leary, C 2015, Rebel Rebel: All the songs of David Bowie from '64 to '76, Zero, Winchester.

Olney, J 1980 (ed.), Autobiography: Essays theoretical and critical, Princeton University Press, Princeton.

Peterson, RA 1997, Creating country music: Fabricating authenticity, University of Chicago Press, Chicago.

Petridis, A 2018, 'Bruce Springsteen: Springsteen on Broadway review: Magical myth-busting with the Boss', The Guardian, 7 December, retrieved 13 February 2019, <https://www.theguardian.com/music/2018/dec/06/bruce-springsteen-springsteenon-broadway-review-magical-myth-busting-with-the-boss $>$.

Pickering, M \& Keightley, E, 2006, 'The modalities of nostalgia', Current Sociology, vol. 54 no. 6, pp. 919-41, doi:10.1177/0011392106068458. 
Rauch, A 1988, 'Bruce Springsteen and the dramatic monologue', American Studies, vol. 29, no. 1, pp. 29-49.

Scobie, S 1991, Alias Bob Dylan, Red Deer College Press, Alberta, 1991.

Simmons, S 2013, I'm Your Man: The life of Leonard Cohen, Vintage, London.

Small, C 1998, Musicking: The meanings of performing and listening, Wesleyan University Press, Middletown.

Smith, S 1995, 'Performativity, autobiographical practice, resistance,' a/b: Auto/Biography Studies, vol. 10, no. 1, pp. 17-33, doi:10.1080/08989575.1995.10815055.

Springsteen, B 2016a, Born to Run, Simon \& Schuster, New York.

- 2016b, Born to Run, audiobook narrated by Bruce Springsteen, Simon \& Schuster Audio, New York.

Springsteen on Broadway 2018, TV Movie, Netflix, USA.

Stein, D \& Butler, M 2015, 'Musical autobiographies: An introduction', Popular Music and Society, vol. 38, no. 2, pp. 115-21, doi:10.1080/03007766.2014.994324.

Streight, I \& Harde, R 2010, 'Introduction: The Bard of Asbury Park', in R Harde \& I Streight (eds), Reading the Boss: Interdisciplinary approaches to the work of Bruce Springsteen, Lexington, Lanham, pp. 1-20.

Swiss, T 2005, 'That's me in the spotlight: Rock autobiographies', Popular Music, vol. 24, no. 2, pp. 287-294.

Trudell, J 1992, 'Baby Boom Ché', on AKA Grafitti Man, CD, Rykodisc, RCD 10223.

Turner, G 2014, Understanding celebrity, second edition, Sage, London.

Watson, P \& Railton, D 2012, 'Rebel without a pause: The continuity of controversy in Madonna's contemporary music videos', in R Jennings \& A Gardner (eds), 'Rock On': Women, ageing and popular music, Ashgate, Farnham, pp. 139-54.

White, H 1980, 'The value of narrativity in the representation of reality', Critical Inquiry, vol. 7, no. 1, pp. 5-27. 